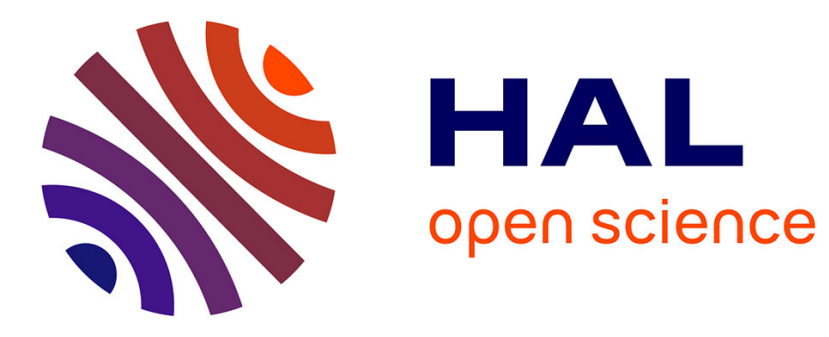

\title{
Moderating the impact of agriculture on climate
}

Bernard Seguin, Dominique Arrouays, Jérôme Balesdent, Jean-François

Soussana, Alberte Bondeau, Pascalle Smith, Sönke Zaehle, Nathalie de

Noblet, Nicolas Viovy

\section{- To cite this version:}

Bernard Seguin, Dominique Arrouays, Jérôme Balesdent, Jean-François Soussana, Alberte Bondeau, et al.. Moderating the impact of agriculture on climate. Agricultural and Forest Meteorology, 2007, $142(2-4)$, pp.278 - 287. 10.1016/j.agrformet.2006.07.012 . hal-01788253

\section{HAL Id: hal-01788253 \\ https://hal-amu.archives-ouvertes.fr/hal-01788253}

Submitted on 31 May 2020

HAL is a multi-disciplinary open access archive for the deposit and dissemination of scientific research documents, whether they are published or not. The documents may come from teaching and research institutions in France or abroad, or from public or private research centers.
L'archive ouverte pluridisciplinaire HAL, est destinée au dépôt et à la diffusion de documents scientifiques de niveau recherche, publiés ou non, émanant des établissements d'enseignement et de recherche français ou étrangers, des laboratoires publics ou privés. 
MODERATING THE IMPACT OF AGRICULTURE ON CLIMATE: AN INTEGRATED ASSESSMENT.

Bernard Seguin $^{\text {a,*}}{ }^{\text {, Dominique Arrouays }}{ }^{\text {b }}$, Jérome Balesdent ${ }^{\text {c }}$, Jean-François Soussana ${ }^{\text {, }}$ Alberte Bondeau ${ }^{e}$, Pascalle Smith ${ }^{\text {e-f }}$, Sönke Zaehle ${ }^{e}$, Nathalie de Noblet ${ }^{f}$, Nicolas Viovy ${ }^{f}$

a. INRA, unité Agroclim, site Agroparc, domaine Saint-Paul, F-84914 Avignon

b. INRA, Unité Infosol, avenue de la pomme de pin, BP 20619, F-45166 Olivet

c. CEA Cadarache, UMR 6191, Département d'Ecophysiologie Végétale et de Microbiologie, F- 13108 Saint Paul Lez Durance

d. INRA, unité d'agronomie, 234 Av du Brézet, F- 63039 Clermont-Ferrand Cedex 02

e. Potsdam Institute for climate impact research ( PIK), D- 14412 Potsdam (Germany)

f. CEA-CNRS, LSCE, Bât. 701 / Orme des merisiers, F- 91191 Gif-sur-Yvette cedex

* corresponding author : e-mail seguin@avignon.inra.fr, fax: 33432722362 


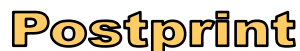

Version définitive du manuscrit publié dans / Final version of the manuscript published in : Agricultural and Forest Meteorology, 2007, vol.142, no.2-4. DOI: 10.1016/j.agrformet.2006.07.012

\section{ABSTRACT}

Many options exist for moderating the influence of agriculture on climate, as discussed elsewhere in this issue; however, difficulties remain in providing a comprehensive set of solutions because several aspects are still poorly understood. This paper presents a comprehensive assessment of the various impacts of agriculture on climate. It focuses on the trade-offs between the relevant greenhouse gases $\left(\mathrm{GHG}-\mathrm{CO}_{2}, \mathrm{~N}_{2} \mathrm{O}\right.$ and $\left.\mathrm{CH}_{4}\right)$, as well as the geochemical and biophysical interactions between agriculture and climate.

The discussion covers three spatial scales: field, farm, and regional or global scale. At the field level, both GHG and energy fluxes are mainly a function of technical decisions by the farmer. At the farm level, strategic decisions for the choice of production systems are mainly governed by economical constraints. Land-use and landscape govern the biophysical aspects which act on the regional climate when spatially integrated. On a global scale, national or regional policies regarding GHG emissions and surface forcings influence global climate. The two aspects of agriculture's contribution to climate (biochemical and geophysical) need to be considered using new approaches in terms of global warming. The use of GCMs appears to be an adequate tool at this scale for assessing the global effect on climate, upon which smaller-scale effects will be superimposed.

KEYWORDS : Agriculture, climate, greenhouse gases, field scale, farm scale, global scale, energy balance, carbon cycle, water cycle 


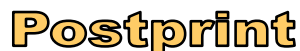

Version définitive du manuscrit publié dans / Final version of the manuscript published in : Agricultural and Forest Meteorology, 2007, vol.142, no.2-4. DOI: 10.1016/j.agrformet.2006.07.012

\section{Introduction}

This contribution can give the impression that the impact of agriculture on climate is basically negative, since it considers the ways to moderate it. This point deserves a short discussion. As stated in various papers of this special issue, agriculture acts on climate through two main processes: the emission or the sequestration of greenhouse gases (GHG) which can modify the atmospheric absorption of terrestrial long-wave radiation (biogeochemical processes) and land cover change, which results in the modification of the surface energy balance and water budget (biophysical processes), which would also have to incorporate biospheric feedbacks linked to vegetation characteristics such as leaf area index, vegetation height, and stomatal conductance. These two main contributions are generally considered separately, but the overall contribution of agriculture to the state of climate needs to be assessed by simultaneously and quantitatively taking them into account, as in Betts (2000) who translated albedo change into carbon equivalent emissions or as suggested by Pielke et al., (2002) who enlarged the approach to consider a new type of measurement called the 'regional climate change potential'.

Hereafter, the term 'moderate' will be taken to mean that the overall contribution of agriculture to climate will be designed to limit, as much as possible, the anthropogenic reinforcement of the global atmospheric greenhouse effect. Currently, our knowledge of biogeochemical and especially biophysical aspects of the influence of agriculture on climate are still too limited for a definitive assessment. Despite this, we give a summary of the 'state of the science' keeping our broad perspective in mind. The focus of the expert meeting for which this paper was prepared considers the opposite of the traditional goal of agricultural meteorology (namely the effect of climate on agriculture). This symmetry has led to adopt the structure generally used in agricultural meteorology by organizing our analysis along the various pertinent space and time scales (Figure $1)$. 


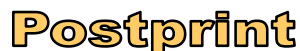

Version définitive du manuscrit publié dans / Final version of the manuscript published in : Agricultural and Forest Meteorology, 2007, vol.142, no.2-4. DOI: 10.1016/j.agrformet.2006.07.012

\section{The field scale $(\sim 100 \mathrm{~m})$}

This scale is generally the first scale for detailed process analysis, because it is amenable to the traditional flux measurement techniques ( Leuning et al (1999), updated by Lassey (2005) for livestock methane emissions). These precise measurements allow for the development, calibration and validation of the modeling approaches which are needed for estimating the magnitude of various GHG emission factors.

This is the basic scale at which farmers impact on GHG emissions within the cropping system through decisions such as the choice of variety, sowing date, irrigation and fertilization scheduling. We may consider the field scale to be the first level at which the numerous interactions between GHGs appear. We present these interactions for crops, and for grasslands.

\section{Crops}

The timing and quantity of fertilizer application, which influences $\mathrm{N}_{2} \mathrm{O}$ emissions, may also modify $\mathrm{CO}_{2}$ exchanges between the crop and the underlying soil. No-till induces an increase in soil carbon levels. Simplified cropping techniques (SCT), defined by no-tillage, cover a broad range of practices, ranging from direct drilling to more or less deep ploughing (but without turning the soil). Direct seeding and minimal soil cultivation would have comparable effects. The increase in carbon sequestration is estimated to be $0.20 \pm 0.13 \mathrm{tC} \mathrm{ha}^{-1}$ year $^{-1}$ (Bruce et al., 1998). No-tillage spreads 'spontaneously' because of the economies in labour it produces. Its widespread acceptance may be limited by the cost of special equipment (drills, machines which limit the packing of soil) and by the agronomic problems it may generate or aggravate (soil compaction, proliferation of weeds or pests, etc.). Efforts to increase soil $\mathrm{C}$ sequestration can result in an increase in $\mathrm{N}_{2} \mathrm{O}$ emissions (Grant et al., 2004). Therefore, it is necessary to evaluate more precisely the impact of no-till on carbon sequestration and $\mathrm{N}_{2} \mathrm{O}$ emissions for soil conservation practices that range between tillage and notill. A single tillage event will reduce carbon stocks accumulated with the adoption of no-till (Arrouays et al. 2002).

The use of green manure (non-harvested production) during sufficiently long intercrop periods (between the summer harvest and spring sowing) represents an interesting option in terms of carbon sequestration, which amounts to $0.15 \mathrm{tC} \mathrm{ha}^{-1}$ year $^{-1}$ for a case study in France (Arrouays et al., 2002). Its introduction in current cash crop systems implies the control of nitrogen input for the 


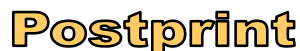

Version définitive du manuscrit publié dans / Final version of the manuscript published in : Agricultural and Forest Meteorology, 2007, vol.142, no.2-4. DOI: 10.1016/j.agrformet.2006.07.012

following crop, while the reconstitution of soil water reserves and the timing of labour requirements must also be considered. The long-term effects (mineralisation and management of nitrogen, parasitism, etc.) of systematically introducing green manure into current cropping systems must be better assessed.

The sowing of permanent grass between rows of vines or fruit trees enables an increase in carbon accumulation nearly equivalent to that induced by converting arable land into permanent grassland, i.e. $0.4 \mathrm{tC} \mathrm{ha}^{-1}$ year $^{-1}$ in France (Arrouays et al., 2002) This practice, which also improves soil bearing capacity, does not pose any specific problems if an adequate water supply is maintained. The widespread application of this practice requires results of ongoing research on the effects of competition for water and nitrogen between the cover plants and the crop, on the possible impact on wine quality and on the control of pests that a maintained grass cover would encourage.

Management practices modify surface biophysical properties in terms of radiative and energy balances. It firstly results on changes in the net radiation $R_{n}$, which represents the balance of absorbed solar radiation (1- $\alpha) \mathrm{R}_{\mathrm{g}}$ and long-wave radiation (corresponding to the difference between downward atmospheric emission $\mathrm{R}_{\mathrm{a}}$ and surface emitted radiation $\mathrm{R}_{\mathrm{s}}$ ): $R_{n=}(1-\alpha) R_{g}-\left(R_{a}-R_{s}\right)$. A change of albedo $\alpha$ affects absorbed shortwave radiation, which in turn influences surface temperature $T_{s}$, and thus terrestrial longwave radiation $R_{s}$. The practices also act on the partition of the radiative available energy $R_{n}$ between sensible $(H)$, latent (LE) and soil heat (G) fluxes. Management practices can also directly modify the local microclimate: for instance, irrigation is able to lower air temperature by up to 2 or $3{ }^{\circ} \mathrm{C}$ (Steinmetz et al, 1989), whilst tillage modes only act on it by some $0.2{ }^{\circ} \mathrm{C}$ but modify soil heat flux by some $20 \mathrm{~W} \mathrm{~m}^{-2}$ ( Richard and Cellier, 1998).

\section{Grasslands}

Grasslands are likely to be a net sink of carbon dioxide, but a source of nitrous oxide (from fertilisation and manuring of soils) and of methane (mainly from the enteric fermentation of ruminants). Since agricultural management is one of the key drivers of the sequestration and emission processes, there is potential to reduce the net GHG flux.

The kinetics of soil organic carbon accumulation following change in land use or in grassland management were found to be (Soussana et al., 2004a): 


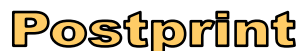

Version définitive du manuscrit publié dans / Final version of the manuscript published in : Agricultural and Forest Meteorology, 2007, vol.142, no.2-4. DOI: 10.1016/j.agrformet.2006.07.012

a) Non linear: they are more rapid during the early years after adopting a practice which enhances accumulation, however there is a plateau.

b) Asymmetrical: for example, the accumulation of organic carbon after sowing a grassland is slower than the release induced by conversion from grassland to arable.

These characteristics have several practical consequences. Any estimate of soil C storage must refer both to the previous management and to the current management. Rates of $\mathrm{C}$ sequestration are highly dependent upon the duration to which they apply. At equilibrium, accumulation no longer increases, but stock conservation requires maintenance of the practices that enabled its accumulation. The cessation or temporary interruption of stock-enhancing practices usually results in a rapid release of carbon to the atmosphere.

Climate change is likely to interfere with the permanence of existing soil carbon stocks and with mitigation strategies aiming at sequestering organic carbon in soils. However, the negative effects of climate change on $\mathrm{C}$ stocks due to higher temperatures and lower summer rainfall might in the long term be counterbalanced by increases in grassland productivity resulting from the rise in atmospheric $\mathrm{CO}_{2}$ concentration (Soussana et al., 2004a).

The European FP5-project GreenGrass has taken over the tasks to (i) assess the carbon sequestration potential of grasslands, (ii) provide estimates of overall greenhouse gas (GHG) emissions, including nitrous oxide (from fertilisation and manuring of soils) and methane (mainly from the enteric fermentation of ruminants) and (iii) develop likely future scenarios of carbon sequestration and greenhouse gas emissions and derive mitigation options at different spatial and temporal scales.

Measurements of net ecosystem exchange (NEE) of $\mathrm{CO}_{2}$ by eddy covariance at 9 European sites indicate a net uptake of carbon at most grassland sites (Soussana et al., 2004b). The NEE of managed ecosystems (meadows and pastures) are highly sensitive to the timing and duration of management practices, such as mowing, grazing and fertiliser application. Lowland ecosystems were found to be appreciable net sinks for $\mathrm{CO}_{2}$, their NEE being of similar magnitude as many temperate European forest ecosystems. However, the exceptionally hot and dry summer conditions in 2003 caused several pasture ecosystems to become net sources for $\mathrm{CO}_{2}$. 


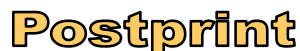

Version définitive du manuscrit publié dans / Final version of the manuscript published in : Agricultural and Forest Meteorology, 2007, vol.142, no.2-4. DOI: 10.1016/j.agrformet.2006.07.012

The net biome productivity (NBP) of grasslands (which accounts for net changes in ecosystem carbon stocks) has been calculated as the NEE, plus organic carbon imports from manure applications, minus organic carbon exports in hay and silage harvests. The NBP was, on average, found to be a carbon sink at the GreenGrass sites, with approximately half of the sink activity resulting from the imports of organic carbon from manure application (Soussana et al., 2004b). On average, when expressed in $\mathrm{CO}_{2}-\mathrm{C}$ equivalents, emissions of $\mathrm{N}_{2} \mathrm{O}$ and $\mathrm{CH}_{4}$ resulted in a $40 \%$ offset of the NEE sink activity of the grasslands at GreenGrass sites. This actual balance of the measured GHG fluxes does, however, not include indirect emissions which are likely to occur from the off site digestion and enteric fermentation of cut hay. An attributed GHG balance has been calculated by adding these indirect emissions, as well as direct $\mathrm{N}_{2} \mathrm{O}$ and $\mathrm{CH}_{4}$ emissions, to the NBP. The attributed GHG balance, including indirect emissions from cut herbage was, on average, found to be neutral (Soussana et al., 2004b).

The IPCC (1996) guidelines are currently being revised. As compared to the recommended default value of $1.5 \%$, results from the GreenGrass sites indicate mean annual values of the emission factor EF1 $\left(\mathrm{N}_{2} \mathrm{O}\right.$ emission per unit $\mathrm{N}$ supply) of $0.93 \%$ (s.d. 1.2), and $0.28 \%$ (s.d. 0.34) in 2002 and 2003, respectively. These values are lower for the dry 2003 year, compared to 2002. Data from manipulative experiments show higher EF1 values for $\mathrm{N}$ from organic fertilisers such as poultry manure and sludge pellets, as compared to inorganic N. Overall, this points to the need to consider emission factors for $\mathrm{N}_{2} \mathrm{O}$ that vary according to the form of nitrogen applied and to the climatic conditions. The emissions of methane by grazing cattle have also been measured consistently at a range of European sites. Results support the concept of a constant rate of $\mathrm{CH}_{4}$ emission per unit metabolic weight for non lactating cattle, while higher emissions were measured for lactating cows (Soussana et al., 2004b). 


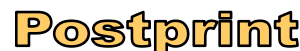

Version définitive du manuscrit publié dans / Final version of the manuscript published in : Agricultural and Forest Meteorology, 2007, vol.142, no.2-4. DOI: 10.1016/j.agrformet.2006.07.012

\section{The farm scale ( 1 to $10 \mathrm{~km})$}

This scale is somewhat specific to agriculture. It is the main scale at which farmers will orient the characteristics of their production system (crops and/or livestock systems, level of mechanization and intensification, etc.), which will act on the GHG balance (Pattey, 2005) as well as on land-use. At this scale, strategic decisions are highly dependent on economic concerns. It is also at this scale that interactions and trade-offs amongst GHGs, through decisions regarding production and irrigation occur, as well as the more general choice of adopting conventional or organic systems, and the consideration of alternative solutions like energy cropping, biofuels, and biogas.

Our understanding of the farm scale is poorer than that of the field scale and there is a need to develop and implement integrated farm-scale models which can make comprehensive assessments of all GHG balances, including indirect $\mathrm{CO}_{2}$ emission through fossil fuel combustion. Recent studies have been made to this effect (see for instance the FASSET model used by Olesen, 2004 ) and they need to be encouraged, since a bottom-up approach could function as an incentive for national policies. A farm-scale model FarmSim has been developed within the GreenGrass project (Soussana et al., 2004b). In a study of nine European cattle farms, the average farm was found to be a net source of GHG. This is a consequence of relatively large emissions from farm buildings, arable crops and waste management systems. From this small farm sample, the rate of emission was found to be strongly influenced by $\mathrm{N}$ fertiliser inputs to the grasslands, as well as with the mean annual cattle stocking density (data not shown). Therefore, intensively managed cattle farms tend to have larger GHG emissions per unit farm area. When calculated per unit product, GHG emissions (ca. $0.54 \mathrm{~kg} \mathrm{CO}-\mathrm{C}$ equivalent $\mathrm{L}^{-1}$ milk) were not significantly different for intensively and extensively managed farms.

At the farm scale, surface biophysical properties are mainly governed by the effects of land-use, as illustrated in Table 1. This dominant effect may be modulated by the cultural practices adopted by farmers. It also interacts with general landscape features. For instance, the use of windbreaks or the presence of trees are both able to significantly modify the regional surface properties such as albedo or surface roughness (Seguin, 1973) and the corresponding climate (see Guyot and Seguin, 1978). Irrigation is also able to act on local/regional climate by lowering air temperature by as much as 1 to $2^{\circ} \mathrm{C}$ (Courault et al., 2004). 


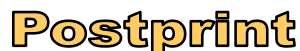

Version définitive du manuscrit publié dans / Final version of the manuscript published in : Agricultural and Forest Meteorology, 2007, vol.142, no.2-4. DOI: 10.1016/j.agrformet.2006.07.012

\section{The regional scale $(\sim \mathbf{1 0 0} \mathbf{k m})$}

This scale spatially integrates the effects already described at smaller scales, but it also takes into account the most significant contribution of land-use (for biogeochemical aspects) and its expression as land-cover (for biophysical aspects). It is mainly governed by regional and national policies.

1 The carbon cycle

In France, the Ministry for Ecology and Sustainable Development has asked the Institut National de la Recherche Agronomique (INRA - France) to carry out a scientific assessment study on the increase of organic carbon stocks in agricultural soils to mitigate the anthropogenic greenhouse effect (Arrouays et al., 2002). It has led to an examination of agricultural land-use change and farming practices.

To assess the rate of carbon sequestration/release occurring after practice $\mathrm{B}$ has been adopted in place of the initial practice A (which is assumed to have attained its stock equilibrium), an exponential function has been adopted (Figure 2). Its parameters are the difference between carbon stocks at the steady state for practices $\mathrm{A}$ and $\mathrm{B}(\Delta \mathrm{C})$, and a constant rate $\mathrm{k}$ of sequestration/release. Thus, it is always possible to calculate a mean annual flux from the stock values. It is these mean flux values that are presented here. For each change in land use or practice, the two parameters have been estimated from the references available, priority being given to data gathered under pedoclimatic and agricultural conditions similar to those prevailing in France and to long-term agronomic experiments.

The study has enabled an evaluation of the mean annual soil carbon storage induced by the afforestation or conversion into permanent grassland of arable land at $0.50 \pm 0.25 \mathrm{tC}^{\mathrm{ha}^{-1}} \mathrm{year}^{-1}$, based on a 20-year scenario. On the other hand, the cultivation of woodland or grassland generates a considerable release of $\mathrm{C}$, twice as rapid as the accumulation which results from afforestation (Figure 3). The afforestation of agricultural land also enables an accumulation of $\mathrm{C}$ in the woody biomass (not included in the context of this report) and has other positive effects on the greenhouse gas budget including a reduction of inputs (nitrogen fertilisers) and an elimination of fossil fuel combustion during tillage, fertilization and harvest. 


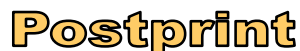

Version définitive du manuscrit publié dans / Final version of the manuscript published in : Agricultural and Forest Meteorology, 2007, vol.142, no.2-4. DOI: 10.1016/j.agrformet.2006.07.012

The variability in estimates of $\mathrm{C}$ sequestration/release is due principally to the diversity of climatic conditions. Conversion of active farmland into managed grassland, which has a high biomass level, accumulates more carbon than the spontaneous development of temporary grass on abandoned arable land.

Farms raising domestic herbivores occupy two-thirds of farmland in France, and $60 \%$ of all professional farms raise some herbivores. However, as illustrated in Figure 4, grasslands (land under permanent grass), which in occupy about one third of mainland France, have markedly declined since 1970, to the benefit of arable land (including fodder crops such as maize silage), fallow land and heath-land.

Restoration over 20 years of half the amount of land under permanent grass lost since the 1970s would lead to a mean annual increase of 90,000 hectares under grasslands, and could be accompanied by a marked increase in soil C stocks. However, this would necessitate major changes to the breeding systems and grassland management practices. In addition, the resultant $\mathrm{CH}_{4}$ and $\mathrm{N}_{2} \mathrm{O}$ emissions, given this management change, are still unknown.

The kinetics of carbon accumulation following change in land use or practices are:

- non-linear: they are more rapid during the first years after adopting a practice which enhances accumulation. This phase does not usually exceed a few decades. If practices remain constant, the stocks tend to remain at a level corresponding to the establishment of a new equilibrium (where the input and mineralization of organic matter compensate for each other).

- slower than those of carbon release, as we have seen before

These characteristics have several consequences: there is a risk of overestimating stocks by extrapolating mean annual fluxes over long periods. Soil stocks do not represent a sustainable, longterm solution to reducing atmospheric $\mathrm{CO}_{2}$ levels. After a few decades, accumulation no longer increases, but stock conservation requires maintenance of the practices which enabled its accumulation. The abandonment or temporary interruption of stock-enhancing practices usually results in rapid release. To be effective, adopting a particular practice must be accompanied by an undertaking concerning its long-term pursuit. If interruptions prove necessary, the stocks claimed must be revised downwards. 


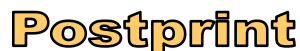

Version définitive du manuscrit publié dans / Final version of the manuscript published in : Agricultural and Forest Meteorology, 2007, vol.142, no.2-4. DOI: 10.1016/j.agrformet.2006.07.012

2 The surface energy balance and water cycle

At this large-scale, Global Circulation models (GCM) are useful for the assessment of the impact of agriculture on climate, as illustrated by Fallon and Betts (2005). Two ongoing European programs are briefly presented here in order to illustrate recent developments on this subject.

The dynamic global vegetation model LPJ (Sitch et al., 2003), which simulates the distribution and the biogeochemical cycles of potential natural vegetation, has been extended in PIK (Potsdam Institute for Climate impact research) in Berlin (Germany) in order to account for land cover change and agriculture (Gerten et al., 2004). In addition to the 10 Plant Functional Types (PFTs) used to describe the functioning of potential natural vegetation, 13 Crop Functional Types (CFTs) are implemented to model phenology and growth of the world's dominant crop and rangeland types. Different management options are specified, e.g., irrigation, removal of residues, natural grass cover during the intercropping season, etc.

Initial model simulations show, as expected, that these different options have a significant impact on soil carbon storage. If the soil is kept bare between two growing periods and the residues are removed, then soil carbon is at a minimum, especially for crops completing their growth cycle over a short period of time.

The model was run at $0.5^{\circ}$ spatial resolution over the 20th Century using the CRU05 monthly climate data set (New et al., 2000) and a yearly distribution of the 13 irrigated or rain-fed CFTs within each grid cell. The land use data were obtained by combining four published data sets available at $0.5^{\circ}$ or higher spatial resolution: changes in cropland area since the end of the 18th Century (Ramankutty and Foley, 1999), worldwide distribution of 19 dominant crops (no grassland) for the 1990s (Leff et al., 2004), geographic distribution of 8 agricultural land use types including grasslands across the world for the 1970s (part of the HYDE database, Klein Goldewijk and Battjes, 1997), and a map of the areas equipped for irrigation in 1995 (Döll and Siebert, 1999). We assumed that no large-scale irrigation existed at the beginning of the 20th Century (except for rice), and that crop distribution within the agricultural area was unchanged throughout the century (this is unrealistic, e.g. the recent increase in soybean cropping at the expense of other crops). Land use change may occur each year with the increase or decrease of the grid cell fraction supporting natural vegetation. When forest is converted to agriculture, the model considers two carbon pools for the removed woody biomass with different turnover times. Approximately two thirds of the woody biomass is considered to be burned or rapidly decomposed, while the rest is considered to be used as long living woody material. This generates a peak in $\mathrm{CO}_{2}$ emission in the years immediately after 


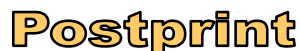

Version définitive du manuscrit publié dans / Final version of the manuscript published in : Agricultural and Forest Meteorology, 2007, vol.142, no.2-4. DOI: 10.1016/j.agrformet.2006.07.012

the deforestation. Conversely, as we have mentioned before, when agricultural land is afforested, soil carbon accumulates slowly until a new equilibrium is reached.

Results of the LPJ model can be evaluated against independent data sets such as seasonal satellite FPAR (phenology), FAO statistical data (yields), or local flux measurements (carbon fluxes). Trends in the global values of a few variables related to the carbon and water cycles of global vegetation are shown in Figure 5, simulated with and without agriculture.

Global cropland area has increased during the 20th Century (Figure 5a). This, combined with increasing productivity mainly due to the overall progress in technology, and partly to the higher atmospheric $\mathrm{CO}_{2}$ concentration and in spite of more adverse climate in some regions, generates increasing productions (Figure 5b). Consequently, a world with agriculture has less carbon stored as biomass (Figure 5c), and less soil carbon (Figure 5d). This result is obtained for management options that do not favour soil carbon storage (e.g. the residues are removed and the soil is kept bare during the intercrop season). Other options could increase the soil carbon of LPJ crops, however such results are extremely difficult to validate.

Nevertheless, it is interesting to use the model over specific regions that faced a strong land use change in order to determine its effect on the carbon cycle and to test the impact of new land use or management change at a large scale. Figures $5 \mathrm{e}$ to $5 \mathrm{~h}$ show the modifications of the global water cycle caused by agriculture. The increase of irrigated areas throughout the $20^{\text {th }}$ century explains the fact that the small difference in global runoff between LPJpot and LPJcrops (more runoff when agriculture is accounted for) at the beginning of the $20^{\text {th }}$ century is reduced when moving toward the end of the $20^{\text {th }}$ century (Figure $5 \mathrm{~h}$ ). In the model, the amount of irrigated water is taken out of the rivers and a large part of it is transpired (i.e. there is less water running out). In reality, irrigated areas draw upon ground water, and it will be necessary to determine how this can change the results. Regarding a possible effect on climate, it is not easy to determine the overall impacts of less annual transpiration and more annual evaporation. The seasonal cycles must be analysed in order to allow the correct application of such a model.

A further step is to couple the LPJ model with a climate model, and some preliminary studies have been made to this effect. For example, in a study that coupled the LPJ model with a climate model of intermediate complexity (CLIMBER-2), Brovkin et al. (2004) showed that the impact of land cover change (the assimilation of croplands to grasslands) on atmospheric $\mathrm{CO}_{2}$ increase during the last 150 years is declining (from $68 \%$ in the first half of the $20^{\text {th }}$ century to $12 \%$ at the end). 


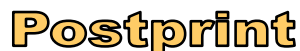

Version définitive du manuscrit publié dans / Final version of the manuscript published in : Agricultural and Forest Meteorology, 2007, vol.142, no.2-4. DOI: 10.1016/j.agrformet.2006.07.012

A complementary work at LSCE (Laboratoire des Sciences du Climat et de l'Environnement) in Saclay (France) aims at evaluating the effects of land-use change (mainly agriculture) on the fluxes of water, energy and carbon (De Noblet et al., 2004), as well as on the climate of Europe. It is based on the global dynamic vegetation model ORCHIDEE (Krinner et al., 2005), with the assimilation of some specific outputs of the crop model STICS using a procedure developed by Gervois et al. (2004). It allows us to quantify the effect of seasonal crops, compared to natural prairies or forests, on the evapotranspiration flux (Figure 6) and on surface temperature.

\section{IV.Interactions between scales}

Even with our improvement in knowledge, unexplained contradictions between scales exist. For instance, the influence of irrigation has been reported by Boucher et al. (2004) to decrease air temperature by $0.8^{\circ}$ over large irrigated areas scale by using a GCM with the most recent documented sources. However, the higher water vapor content induced by large scale irrigation has been computed to increase the anthropogenic radiative forcing by 0.03 to $0.1 \mathrm{~W} \mathrm{~m}^{-2}$. Consequently, the net effect of irrigation could be the combination of global warming, which will take place after a long and complex trajectory through the atmosphere, and a local instantaneous cooling due to an increase in the latent heat flux. This example confirms the complexity of the whole set of influences of agriculture on climate and the need to better understand all the possible interactions before giving recommendations in order to moderate it.

\section{Conclusions}

As shown in this issue, the effect of agriculture on climate is significant. It combines geochemical aspects through GHG emission and absorption, which acts indirectly on future climate and biophysical aspects through the modification of surface properties which act directly at different spatial scales. The complete evaluation of the net impact of agriculture on climate through the modification of the natural environment is a substantial task, and is still not feasible. Valuable technical knowledge exists for the partial estimation of the effect of one single aspect, but comprehensive studies are still lacking. However, recent attempts at the farm level to take into account the various trade-offs between GHGs, and the development of new tools which can quantitatively combine geochemical and biophysical global aspects give hope for progress towards this goal. 


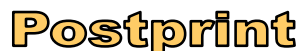

Version définitive du manuscrit publié dans / Final version of the manuscript published in : Agricultural and Forest Meteorology, 2007, vol.142, no.2-4. DOI: 10.1016/j.agrformet.2006.07.012

\section{References}

Arrouays D., Balesdent J., Germon J.C, Soussana J.F., Stengel P. 2002. Increasing carbon stocks in French agricultural soils? Synthesis of an assessment report, INRA Paris, 33 p.

Betts, R.A., 2000. Offset of the potential carbon sink from boreal forestation by decreases in surface albedo. Nature. 408, 187-189

Boucher O., Myhre G., Myhre. A., 2004. Direct human influence of irrigation on atmospheric water vapour and climate. Climate Dynamics. 22, 597-603.

Brovkin, V., Sitch, S., Von Bloh, W., Claussen, M., Bauer, E., Cramer, W. 2004. Role of land cover changes for atmospheric $\mathrm{CO}_{2}$ increase and climate change during the last 150 years, Global Change Biology. 10, 1-14.

Bruce, J., Frome, M., Haites, E., Janzen, H., Lal, R., Paustian, K., 1998. Carbon sequestration in soils. Journal of Water Conservation. 54, 382-389.

Courault, D.,Olioso, A., Lagouarde, J.P., Monestiez, P., Allard, D., 2004. Influence des cultures sur les variables climatiques. In : Monestiez, P., Lardon, S., Seguin, B. (Eds.), Organisation spatiale des activités agricoles et processus environnementaux, INRA Paris, Science update, 303-320.

De Noblet, N., Gervois, S., Ciais, P., Viovy, N., Brisson, N., Seguin B., Perrier, A., 2004. Coupling the Soil-Vegetation-Atmosphere-Transfer Scheme ORCHIDEE to the agronomy model STICS to study the influence of croplands on the European carbon and water budgets. Agronomie. 24, 397-407.

Döll, P., Siebert, S., 1999. A Digital Global Map of Irrigated Areas - Documentation. Kassel, University of Kassel: 1-43.

Falloon, P., Betts, A., 2005. Biophysical forcing of climate by anthropogenic vegetation change. Agricutural and Forest Meteorology. (this issue).

Gerten, D., Bondeau, A., Hoff, H., Lucht, W., Schaphoff, S., Smith, P. 2004. Assessment of 'green'water fluxes with a Dynamic Global Vegetation model. In : Hydrology: Science \& Practice 


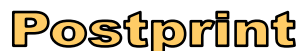

Version définitive du manuscrit publié dans / Final version of the manuscript published in : Agricultural and Forest Meteorology, 2007, vol.142, no.2-4. DOI: 10.1016/j.agrformet.2006.07.012

for the21st Century. Webb, B., Arnell, N., Onofet.C. (eds.), British Hydrological Society. 1, 2935.

Gervois, S., De Noblet, N., Viovy, N., Ciais, P., Brisson, N., Seguin, B., Perrier,A., 2004. Including croplands in a global biosphere model: methodology and evaluation on specific sites. Earth Interactions, 'Land-use' special issue. 8, 1-25

Grant, B., Smith, W.N., Desjardins, R., Lemke, R., Li. C. 2004. Estimated $\mathrm{N}_{2} \mathrm{O}$ and $\mathrm{CO}_{2}$ emissions as influenced by agricultural practices in Canada. Climatic Change. 65, 315-332.

IPCC, 1996. Revised Guidelines for national greenhouse gas inventories, Cambridge University press, also available on-line at $:<w w w . i p c c . c h>$

Guyot, G., Seguin, B., 1978. Influence du bocage sur le climat d'une petite région: résultats des mesures effectuées en Bretagne. Agricultural Meteorology 19, 411-430.

Klein Goldewijk, K, Battjes, J.J. 1997. A hundred year (1890-1990) database for integrated environmental assessments (HYDE, version 1.1). Bilthoven, The Netherlands, National Institute of Public Health and the Environment (RIVM).

Krinner, G., Viovy, N., de Noblet-Ducoudré, N., Ogée, J., Friedlingstein, P., Ciais, P., Sitch, S., Polcher, J., Prentice, I.C., 2005. A dynamical global vegetation model for studies of the coupled atmosphere-biosphere system. Global Biogeochemical Cycles (in press).

Lassey, K. 2005. Livestock methane emissions: measurements, methods, inventory estimation, and the global methane cycle. Agricultural and Forest Meteorology (this issue).

Leff, B., Ramankutty, N., Folley, J. 2004. Geographic distribution of major crops across the world. Global Biogeochemical Cycles. GB1009, doi:10.1029/2003GB002108.

Leuning,R., Denmead, O.T., Griffith, D.W.T., Harper, L.A., Freney, J.R., Jamie, I.M., Turatti, F., 1999. Verifying current estimates of non- $\mathrm{CO}_{2}$ greenhouse gas emissions from animals, landfills and 


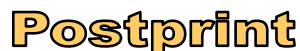

Version définitive du manuscrit publié dans / Final version of the manuscript published in : Agricultural and Forest Meteorology,

pastures with direct measurements, Comptes Rendus de l'Académie d'Agriculture de France 85, 102-135.

New, M., Hulme, M., Jones, P., 2000. Representing twentieth-century space-time climate variability.Part II: Development of 1901-1996 monthly grids of terrestrial surface climate. Journal of Climatology 13, 2217-2238.

Olesen, J.E., 2004. A farm scale approach to reducing net greenhouse emissions from agriculture, In: Jacobsen, S.E., Jensen, C.R., Porter, J.R. (Eds.). European agriculture in a global context, Book of proceedings of the VIII European Society of Agronomy, KVL, Copenhagen, Denmark, 779-780.

Pattey, E., 2005. Tools for quantifying GHG emissions from agrosystems, Agricultural and Forest Meteorology (this issue)

Pielke, R.A. Sr., Marland, G., Betts, R.A., Chase, T.N., Eastman, J.L., Niles, J.O., Niyogi, D.D., Running, S.W., 2002. The influence of land-use change and landscape dynamics on the climate system: relevance to climate-change policy beyond the radiative effect of greenhouse gases, Philosophic Transactions of the Royal Society London 360, 1715-1719.

Ramankutty, N., Foley, J.A. 1999. Estimating historical changes in global land cover; croplands from 1700 to 1992. Global Biogeochemical Cycles. 13, 997-1028.

Richard, G., Cellier, P., 1998. Effect of tillage on bare soil energy balance and thermal regime: an experimental study, Agronomie. 18, 163-181

Seguin,B., 1973. Rugosité du paysage et évapotranspiration potentielle à l'échelle régionale.

Agricultural Meteorology. 11, 79-98.

Sitch, S., Smith, B., Prentice, I.C., Arneth, A., Bondeau, A., Cramer, W., Kaplan, J.O., Levis, S., Lucht, W., Sykes, M.T., Thonicke, K., Venesky., S., 2003. Evaluation of ecosystem dynamics, plant geography and terrestrial carbon cycling in the LPJ Dynamic Global Vegetation Model. Global Change Biology. 9, 161-185. 


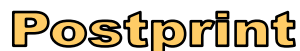

Version définitive du manuscrit publié dans / Final version of the manuscript published in : Agricultural and Forest Meteorology, 2007, vol.142, no.2-4. DOI: 10.1016/j.agrformet.2006.07.012

Soussana, J.F., Loiseau, P., Vuichard, N., Ceschia, E., Balesdent, J., Chevallier, T., Arrouays, D. 2004a. Carbon cycling and sequestration opportunities in temperate grasslands. Soil Use and Management. 20, 219-230

Soussana, J.F., Salètes, S., Smith, P., Schils, R., Ogle, S. 2004b. Greenhouse Gas Emissions from European Grasslands, In ' Sezzi, E., Valentini.R., (Eds), 'Report 4/2004, Specific Study 3, CarboEurope GHG, Concerted Action, Synthesis of the European Greenhouse Gas Budget.', University of Tuscia, Viterbo, Italy. ISSN1723-2236

Steinmetz, S., Lagouarde, J.P., Delecole, R., Guerif, M., Seguin, B.,1989. Evapotranspiration and water stress using thermal infrared measurements. A general review and a case study on winter durum wheat in southern France. In : Symposium on Physiology-breeding of winter cereals for stressed mediterranean environments, ICARDA-INRA, July 3-6 1989, Montpellier. Proc. ed. By INRA Paris, 89-114.

Table 1

The effect of land- cover on the surface radiative balance components in $\mathrm{W} \mathrm{m}^{-2}$, assuming the following inputs $\mathrm{R}_{\mathrm{g}}=1000, \mathrm{R}_{\mathrm{a}}=300$ and $\mathrm{Ta}=17^{\circ} \mathrm{C}$. $\alpha$ is the albedo and Ts the surface temperature

\begin{tabular}{ccccccc}
\hline Surface & $\alpha$ & $(1-\alpha) \mathrm{R}_{\mathrm{g}}$ & $\mathrm{T}_{\mathrm{s}}$ & $\mathrm{R}_{\mathrm{s}}$ & $\mathrm{R}_{\mathrm{s}}-\mathrm{R}_{\mathrm{a}}$ & $\mathrm{R}_{\mathrm{n}}$ \\
\hline snow & 0.7 & 300 & 0 & 315 & 15 & 275 \\
desert & 0.4 & 600 & 40 & 544 & 244 & 366 \\
bare soil & 0.25 & 750 & 35 & 512 & 212 & 528 \\
dry pasture & 0.25 & 750 & 30 & 479 & 179 & 581 \\
irr. pasture & 0.2 & 800 & 22 & 431 & 131 & 669 \\
forest & 0.1 & 900 & 18 & 408 & 108 & 792 \\
\hline
\end{tabular}




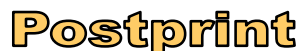

Version définitive du manuscrit publié dans / Final version of the manuscript published in : Agricultural and Forest Meteorology, 2007, vol.142, no.2-4. DOI: 10.1016/j.agrformet.2006.07.012

List of figure captions

Fig.1 The spatial and temporal scales of climate (mn for minute, hr for hour, mo for month)

Fig 2. Two methods can be used to approximate carbon stock kinetics for practice B replacing a different practice A. The IPCC uses the bounded linear approximation. An exponential approximation defined by the equation $C_{t}=\Delta C\left(1-\mathrm{e}^{-k t}\right)$, is shown here. The exponential best fit line more closely approximates observed data than that linear best fit line. Overestimation of the $\mathrm{C}$ stocks due the summation of fluxes over an excessively long period of time can be accomplished with an asymptote.

Fig 3. Change in soil carbon stocks associated with practices which enhance sequestration or emission. These are modal values for mainland France. The 95\% confidence interval of these values is about $\pm 40 \%$

Figure 4. Land use effects on the computed soil carbon storage in France, with : 1 disappearance of fallow practices, 2 increase of permanent grasslands, 3 afforestation, 4 increase of artificial surfaces like urban areas, roads, industries, 5 conversion from grasslands to croplands, 6 bare soil fallow from European Common Agricultural Policy requirements. The shaded area corresponds to the range of estimates.

Fig 5. a: 20th century trend in global cropland area (Ramankutty and Foley, 1999). b to h: Global trends of selected LPJ outputs: in grey LPJ was run for natural potential vegetation only, in black LPJ considers both natural vegetation and agriculture, including land use change.

Figure 6. Time variation of regionally (averaged over Europe) latent heat (expressed as evapotranspiration in $\mathrm{mm} /$ day) fluxes simulated with ORCHIDEE-STICS under present-day climatic conditions. The black curve corresponds to the whole Europe covered with natural vegetation and the grey curve incorporates the presence of cultivated crops on all croplands 


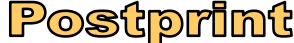

Version définitive du manuscrit publié dans / Final version of the manuscript published in : Agricultural and Forest Meteorology, 2007, vol.142, no.2-4. DOI: 10.1016/j.agrformet.2006.07.012

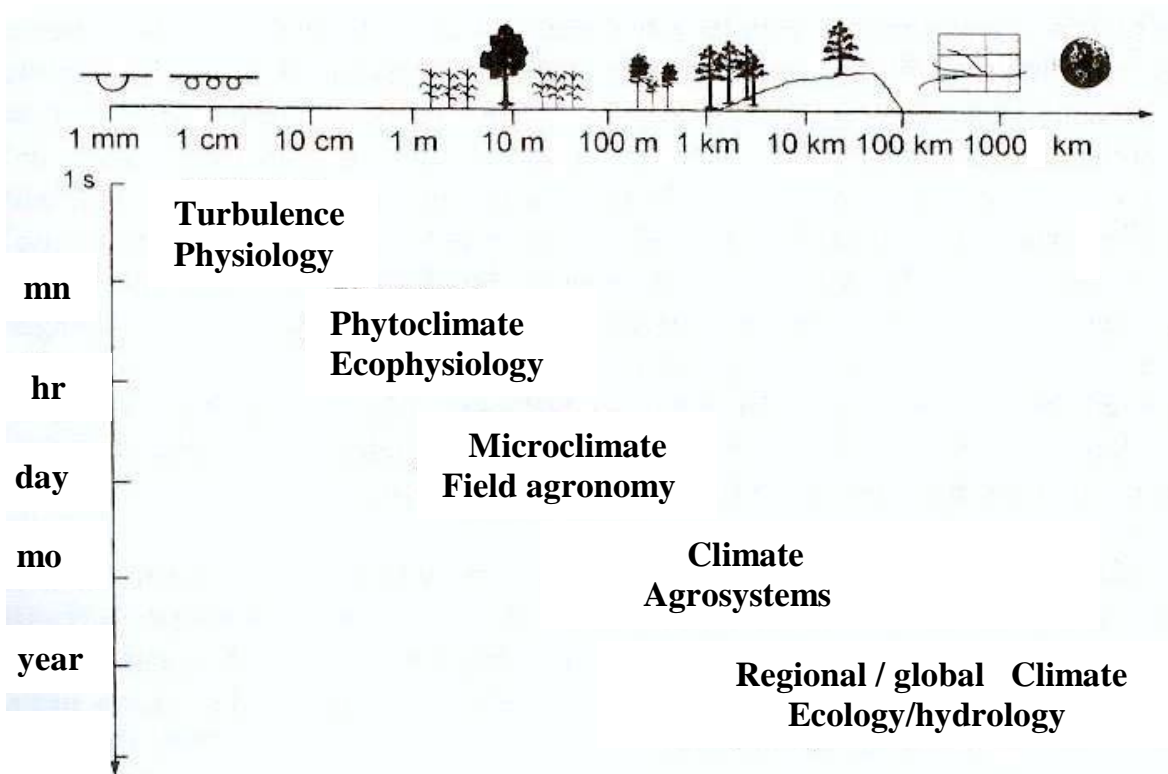




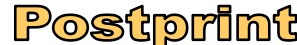

Version définitive du manuscrit publié dans / Final version of the manuscript published in : Agricultural and Forest Meteorology,

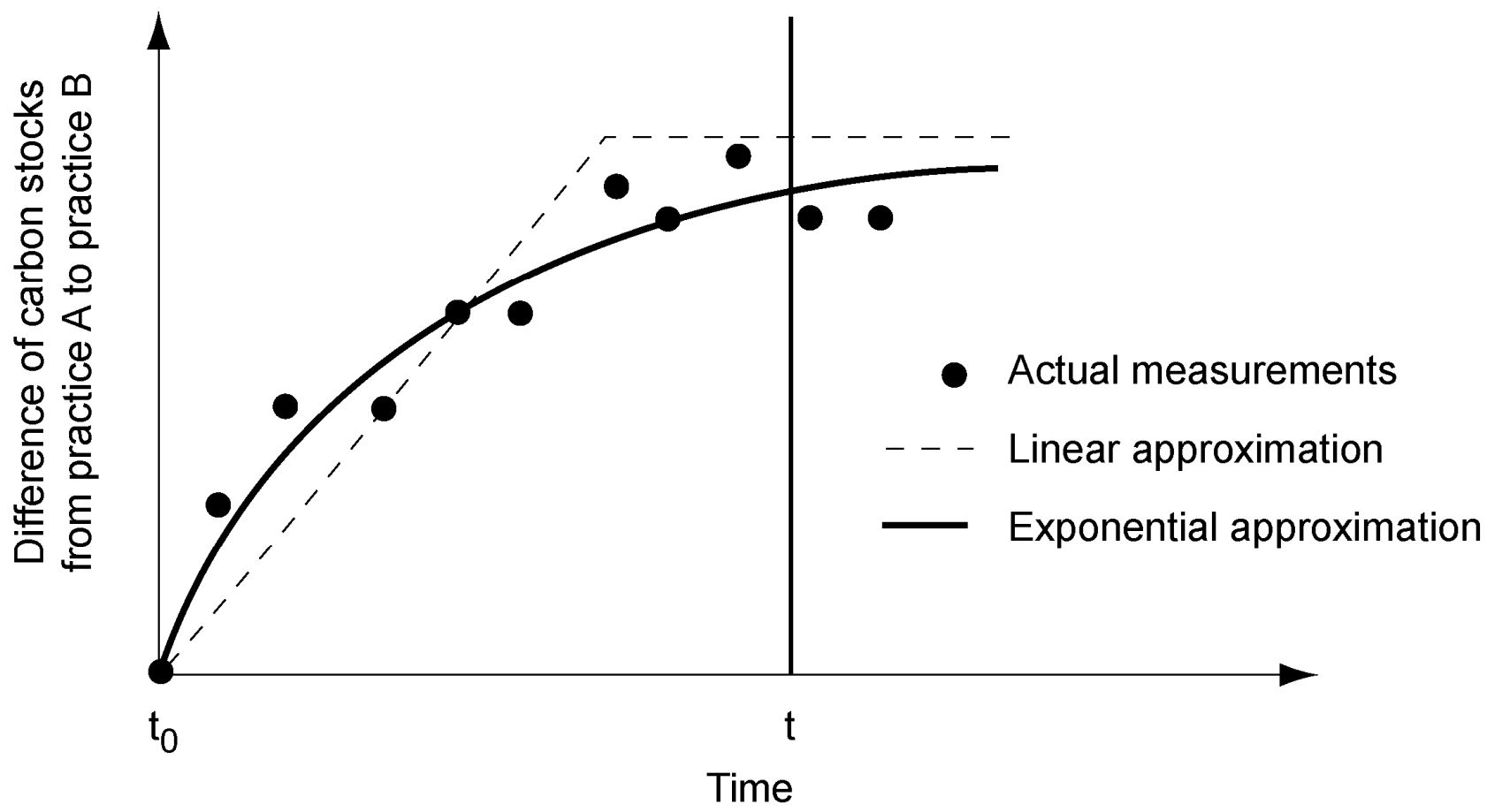




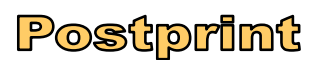

Version définitive du manuscrit publié dans / Final version of the manuscript published in : Agricultural and Forest Meteorology,

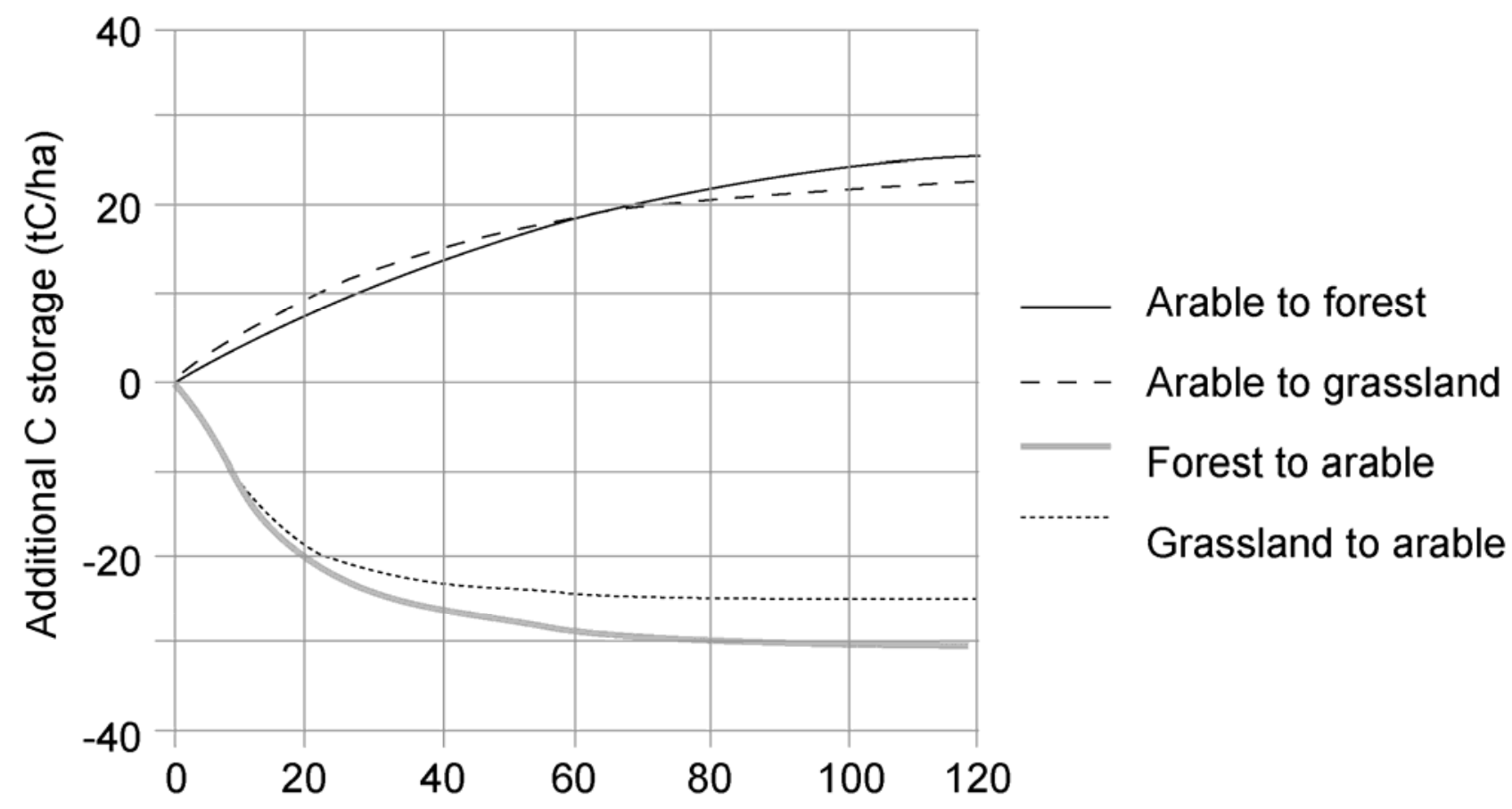

Duration of application (years) 


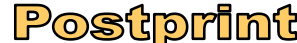

Version définitive du manuscrit publié dans / Final version of the manuscript published in : Agricultural and Forest Meteorology, 2007, vol.142, no.2-4. DOI: 10.1016/j.agrformet.2006.07.012

4

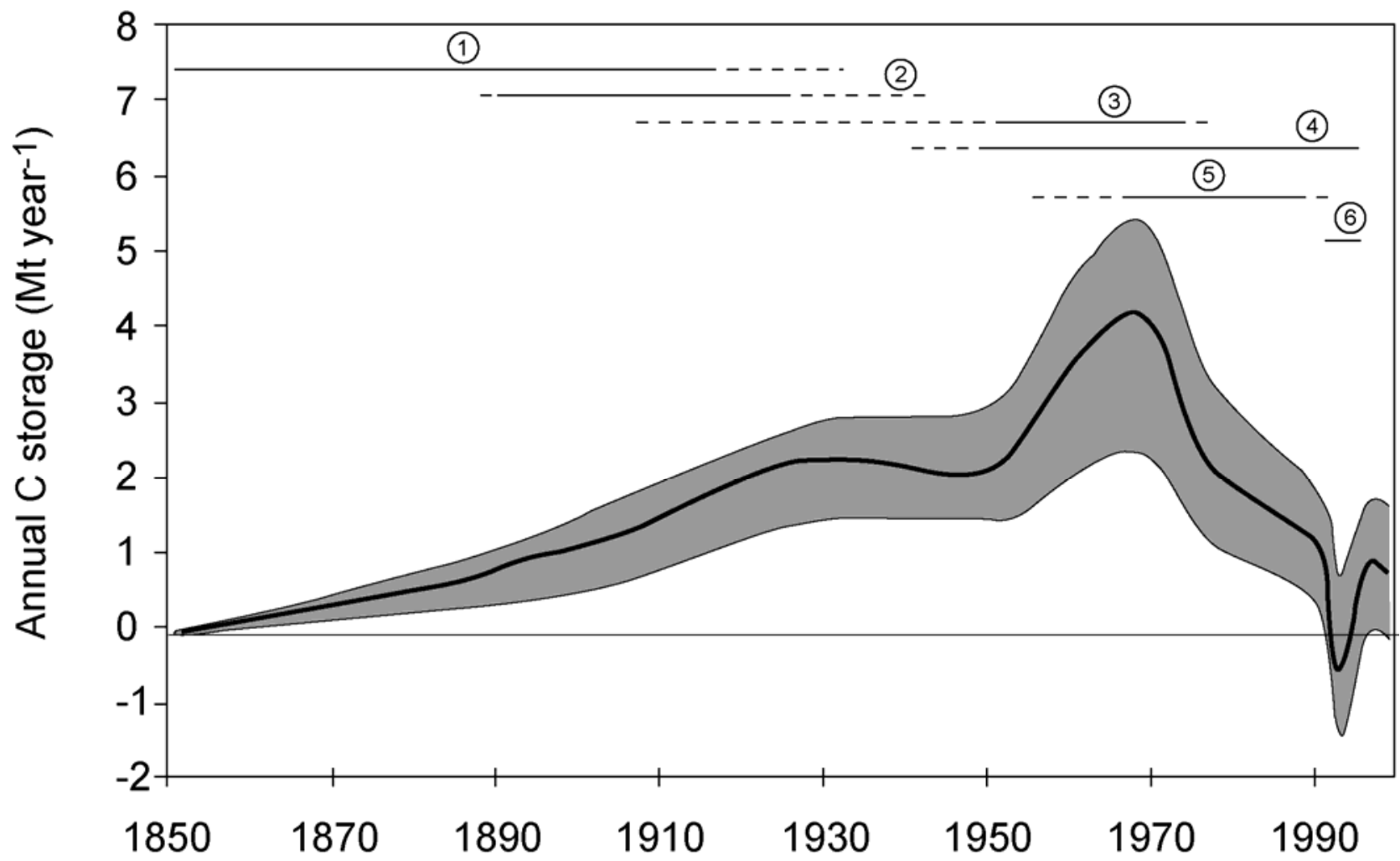

Date 


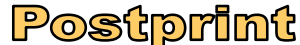

Version définitive du manuscrit publié dans / Final version of the manuscript published in : Agricultural and Forest Meteorology, 2007, vol.142, no.2-4. DOI: 10.1016/j.agrformet.2006.07.012
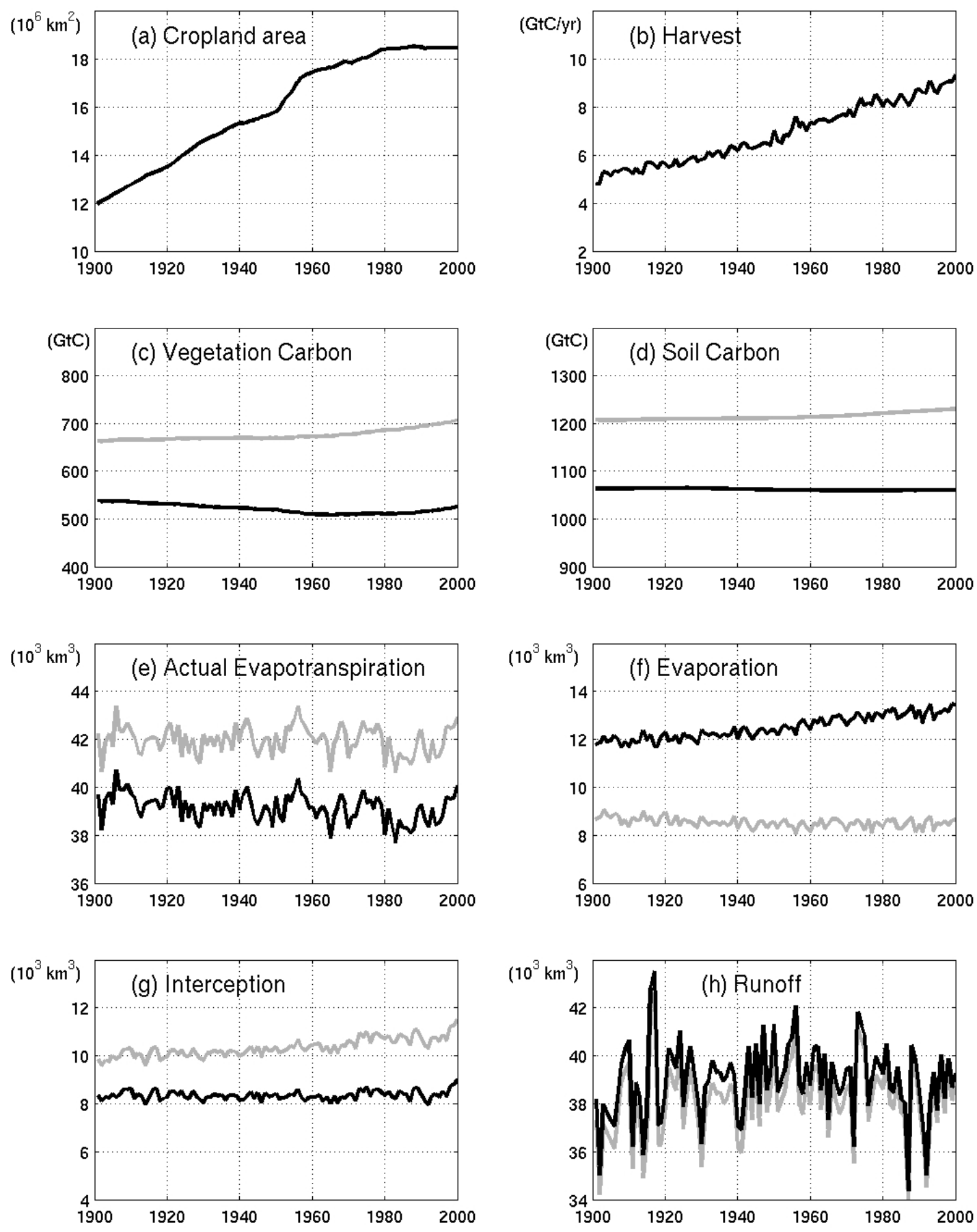


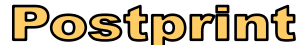

Version définitive du manuscrit publié dans / Final version of the manuscript published in : Agricultural and Forest Meteorology, 2007, vol.142, no.2-4. DOI: 10.1016/j.agrformet.2006.07.012
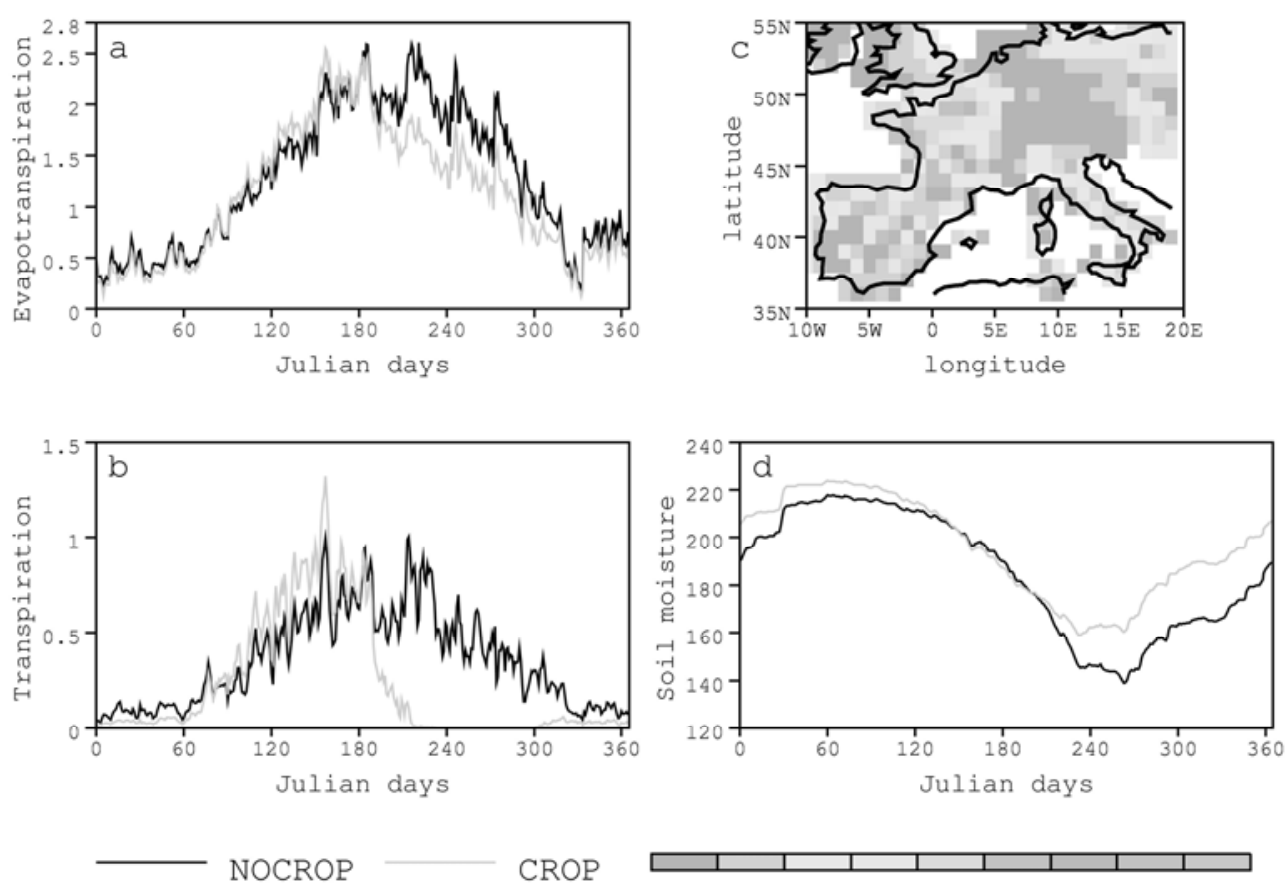

CROP

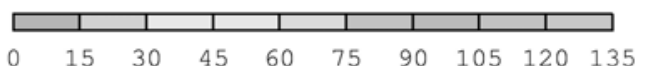

6 